\title{
Venipuncture by Viper Bite: Report of 2 Clinical Casent in Children at the Mali Hospital
}

Kané Bourama ${ }^{1 *}$, Camara $\mathrm{MA}^{2}$, Traoré $\mathrm{MM}^{2}$, Diallo $\mathrm{KW}^{1}$, Touré $\mathrm{BM}^{2}$, Koné $\mathrm{O}^{4}$, Dramé A.S.I ${ }^{3}$, Diallo Baba ${ }^{5}$, Kané Aboubacar $\mathrm{ST}^{5}$

\author{
${ }^{1}$ Department of Pediatrics of the Hospital of Mali \\ ${ }^{2}$ Department of Medicine of the Hospital of Mali \\ ${ }^{3}$ Mali Hospital Blood Bank Unit \\ ${ }^{4}$ Malaria Research and Training Center / Department of Epidemiology of Parasitic Diseases \\ ${ }^{5}$ Odontology Service, Military Hospital of Bamako IHB
}

DOI: $10.36347 /$ sjmcr.2020.v08i05.003

| Received: 27.04.2020 | Accepted: 04.05.2020 | Published: 06.05.2020

*Corresponding author: Bourama Kané

\section{Abstract}

Introduction: Snake bites are a public health problem in the world. The incidence of snake bites is higher in children than in adults. An estimated 2.4 million envenomation which causing 94,000 to 125,000 deaths each year. We are reporting 2 clinical envenomation cases in two children admitted in the department of Pediatric at Hôpital du Mali. Observation: It was a girl aged 7 and a boy aged 14 bitten by vipers in the fields. The girl did not receive antivenom because her family opted for traditional treatment. One month after the accident, she was admitted for obsession. An emergency brain scan revealed a subarachnoid hemorrhage associated with an extradural hematoma which resolved spontaneously after 10 days of treatment. The second victim was admitted for coma and necrosis of the 2 nd right toe despite the administration of antivenom on the day of the bite. The brain scan and lumbar puncture confirmed the subarachnoid hemorrhage. He died a few hours after his admission. Conclusion: Management of snake-bite edema is problematic in rural areas because of the disruption and high cost of antivenom, but also because of the use of medicinal plant as a first-line treatment.

Keywords: envenimation-viper-pediatrics-Mali Hospital.

Copyright @ 2020: This is an open-access article distributed under the terms of the Creative Commons Attribution license which permits unrestricted use, distribution, and reproduction in any medium for non-commercial use (NonCommercial, or CC-BY-NC) provided the original author and source are credited.

\section{INTRODUCTION}

Snake bites are a major public health problem for children and adults around the world. The incidence of snakebites is higher in children than in adults, and generally children have a more serious clinical picture than adults by the simple fact that the amount of venom injected is proportionally greater compared to their weight [1].

Globally, up to 5 million people fall victim to snakebites each year. Among these, poisonous snake bites are responsible for significant morbidity and mortality. It is estimated that 2.4 million people are poisoned and 94,000 to 125,000 are killed each year $[1,2]$.

The majority of snake bites occur in Africa and Southeast Asia. They mainly affect people living in poor rural areas, who live on non-mechanized agriculture [2].
In 2005 a study carried out in the province of Bas Congo on the poisoning by bite of the viper revealed a frequency of $35.9 \%$ with $10.2 \%$ of deaths [3].

In 2005 a study carried out in Senegal in rural areas indicated an incidence of viper bite 677/100000 inhabitants with an average annual mortality rate of 14/100000 inhabitants [4].

In 2006, a prospective study carried out at the Niamey National Hospital showed $7 \%$ poisoning by viper bite with $15 \%$ lethality [5].

In Mali, a study carried out on adults at the Mother and Child University Hospital Center in "Luxembourg" showed an annual average of 6.7 cases] $6]$.

We report 2 clinical cases of poisoning by viper bite in 2 children cared for in the pediatrics department of the Mali Hospital. 


\section{ObServation 1}

DD a 7 year old girl hospitalized for coma after a viper bite. These parents were peasants without known medical and surgical ATCD.

While picking a flower, DD was bitten by a viper camouflaged on a shrub. His family treated him with traditional methods for a month without success. Before the appearance of a change in consciousness, she was referred to the hospital for better treatment.

On entry the weight was $20 \mathrm{~kg}$ and a fever at $38.2^{\circ} \mathrm{C}$. His general condition was altered. The conjunctiva was pale. Consciousness was impaired with a Glasgow score of 10 out of 15 with subarachnoid stiffness. The rest of the exam was normal.

In summary, it was a 7-year-old girl without known medical and surgical ATCD, admitted for febrile coma 26 days after a viper bite traditionally treated, we mentioned two diagnostic hypotheses, namely severe malaria, neurological form with sequelae. poisoning and meningitis after poisoning aftereffects.

An emergency CT scan of the brain revealed a recent bruising of the right frontal frontal area with little compression, with a subarachnoid and ventricular hemorrhage associated with diffuse cerebral edema (Figure 1 and 2).

The coagulation balance requested for this purpose was not disturbed (TP: $78.3 \%$, TCA: $33.8 \mathrm{sec}$ ).

The NFS showed a neutrophil predominantly neutrophilic hyperleukocytosis at $17,500 / \mathrm{mm} 3$, anemia at $9.1 \mathrm{~g} / \mathrm{dl}$ and the platelets at 150,000/ mm3. CRP was positive at $16 \mathrm{mg} / \mathrm{dl}$ and serum creatinine was 34 $\mu \mathrm{mol} / \mathrm{l}$

A treatment combining ceftriaxone $100 \mathrm{mg} /$ $\mathrm{Kg} /$ day in IVD in a single injection, gentamycin $3 \mathrm{mg}$ / $\mathrm{Kg}$ diluted in $8 \mathrm{ml}$ of saline serum $0.9 \%$ in IVL, paracetamol $15 \mathrm{mg} / \mathrm{Kg} / 6$ hours in IVL and the glucose serum $100 \% \mathrm{ml} / \mathrm{kg} /$ day was established.

After 3 days of treatment we observed apyrexia, improved consciousness and bilateral blindness which gradually improved with the resorption of extradural hematoma and subarachnoid hemorrhage.

\section{ObServation 2}

MF, a 14 year old boy hospitalized for coma and stiff neck. These parents were peasants without known medical and surgical ATCD.

MF was the second child of six children. All of his siblings are alive and well except for a little brother whom he lost during the neonatal period.
MF was bitten by a viper in the second right toe during field work. A few minutes after the accident, after killing the snake, his family took him to their local health center, where he received the antivenom after the wound was cleared. Three days later he vomited, and complained of severe headache. Before the onset of a disturbance in consciousness, his family deemed it necessary to consult the hospital for better treatment.

At admission the weight was $22 \mathrm{~kg}$ and the temperature $37.5^{\circ} \mathrm{C}$. He had a poor general condition and very marked conjunctival pallor.

Consciousness was impaired with a Glasgow score of 9 on a scale of 15 . He presented with subarachnoid stiffness with the presence of Kerning and Brudzensky signs. The second right toe which was bitten, showed signs of necrosis. The rest of the clinical examination was without much particularity.

In summary, it was a 14 year old boy bitten by a viper who is admitted in a pallor picture with a frank meningeal syndrome in an apyretic context, we have evoked the hypothesis of a subarachnoid hemorrhage by envenomation by Viperine bite.

An emergency lumbar puncture revealed a subarachnoid hemorrhage with cerebrospinal fluid (CSF) hemorrhagic fluid that did not coagulate. The CSF cytobacteriological examination showed more than 1,000 red blood cells (GR) / $\mathrm{ml}$ and 1 white blood cell (GB) $/ \mathrm{ml}$. There were no germs on direct examination and culture.

The cerebral computed tomography (CT) showed a significant subarachnoid hemorrhage (Figure 3: A, B, C).

The blood cell count (NFS) showed anemia at $10.6 \mathrm{~g} / \mathrm{dl}$ microcytic, hyperleukocytosis at $12200 /$ $\mathrm{mm} 3$ and a platelet count at $152000 / \mathrm{mm} 3$. Reactive protein C (CRP) was $53 \mathrm{mg} / \mathrm{dl}$. The renal function was normal with a serum creatinemia at $78 \mu \mathrm{mol} / 1$. It was during the blood coagulation test that the patient died.

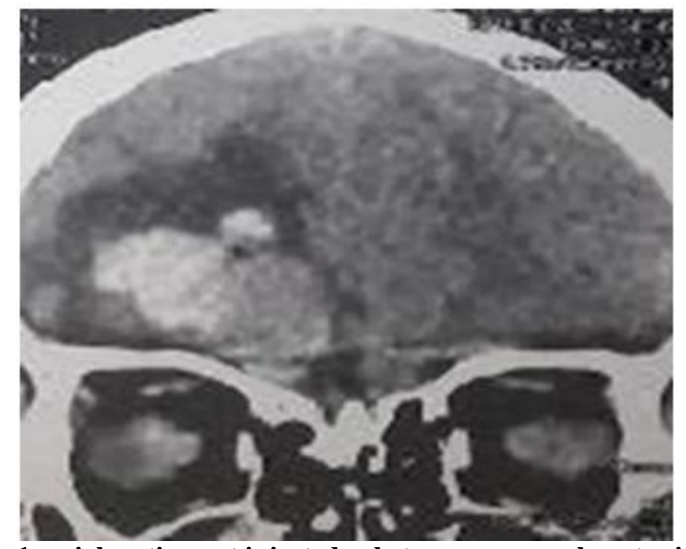

Fig-1: axial section not injected, a heterogeneous subacute right hematoma with peri-lesional edema 


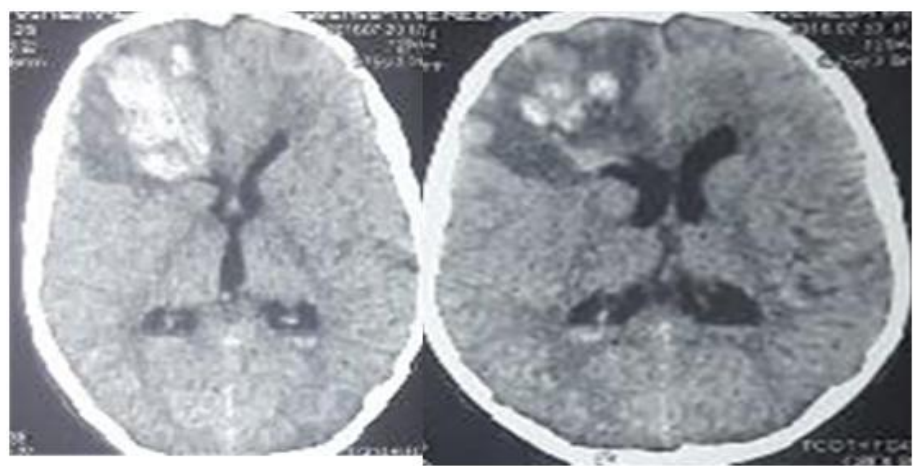

Fig-2: Uninjected axial sections showing a right subacute hematoma with peri-lesional edema
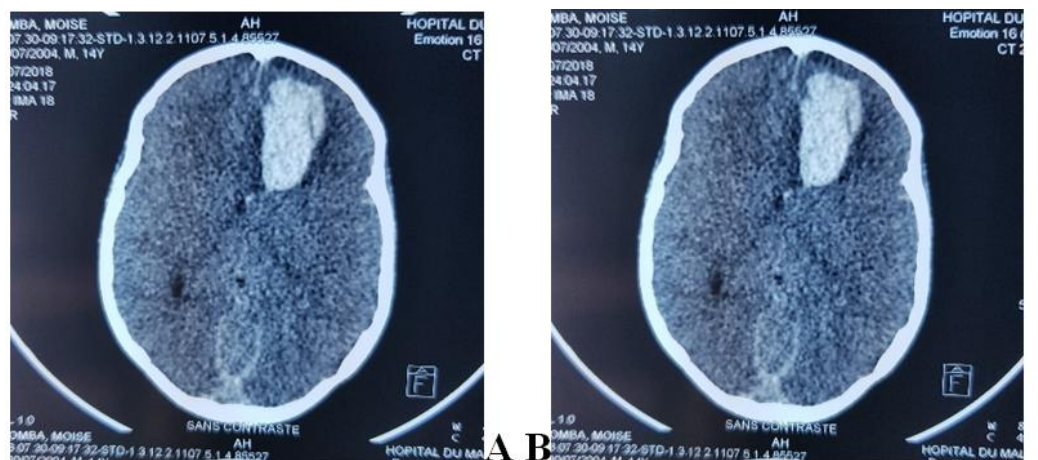

C

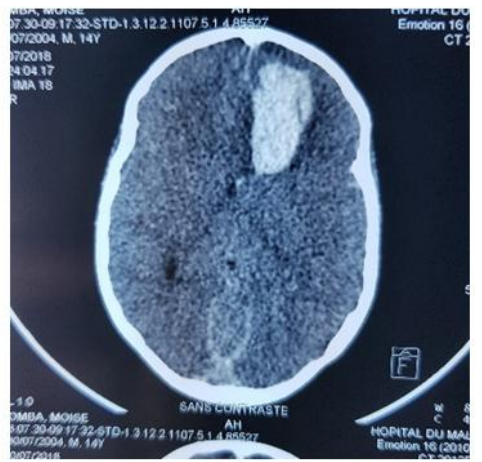

Fig-3: A, B, C: CT scan of the brain: subarachnoid hemorrhage

\section{DISCUSSION}

The envenomation is the result of the pharmacological action of the venom and the reaction of the organism which results from it. The viperidae venom is essentially composed of enzymes which transform the substrates into compound into new compound with pharmacological action and very variable structure. Hyaluronidase hydrolyzes mucopolysaccharides and promotes the spread of toxic substances from the venom. Thrombin enzymes hydrolyze fibrinogen. The clot formed can be very variable in nature depending on the species involved and the specificity of the enzyme. Its volume, its stability and its sensitivity to plasmin will explain the diversity of clinical expressions and the great variability in responding to treatment [7].

The viper syndrome divided into inflammatory and necrotic syndrome. Haematological disorders are often present but constitute a very distinct entity both in terms of etiology and evolution [8].

Local inflammation is rapid. The pain is intense and often dominates the clinical picture. Progressive onset edema sets in within minutes. The skin often shows hemorrhagic signs (bruises, petechiae, purpura) [7].

Biologically, there is a leukocytosis at more than $12,000 \mathrm{~GB} / \mathrm{mm} 3$, proteinuria and a positive CRP. Necrosis e can result from local anoxia which leads to localized gangrene which develops over several days [7].
The venoms of the Echis vipers cause a major hemorrhagic syndrome while necrosis is rare. The thrombin enzymes of Echis and Bitis directly attack fibrinogen, although their molecular structure is different from thrombin (which explains the ineffectiveness of heparin and hirudin]. Echis carinatus also has a glycoprotein transforming prothrombin in thrombin and enzymes such as scarlet able to initiate platelet aggregation or carinatin and echistaline, which, on the contrary inhibit it. After a possible hypercoagulability phase of a few hours disseminated venous coagulation (DIC) causes prolonged bleeding next to the bite, at the puncture site, purpura, epistaxis, hematuria, hemoptysis or rectal bleeding, metrorrhagia or even subarachnoid hemorrhage, generally fatal. hypovolemia or vagal reaction only of venom cardiotoxicity, except sarafotoxin from vipers of the family s actractaspidae [9].

Haematological abnormalities frequently precede clinical manifestations of the hemorrhagic syndrome. In tropical countries, a hemostasis disorder can be diagnosed by a dry tube coagulation test (TC, TS), which draws blood from a dry, clean, detergentfree tube. The absence of a clot within 30 minutes or the formation of an abnormal clot translates, even outside clinical symptoms suggestive, a viperine envenomation requiring appropriate treatment [7].

At the scene of the accident, it is desirable to reduce the gestures to those likely not to aggravate the toxic process. The victim should be reassured, if possible lie down and immobilize the bitten limb with 
an loose bandage. Evacuation to a medical center where the bandage will be removed is undertaken urgently [7].

Most maneuvers are to be avoided. The tourniquet increases the ischemia already suffered by the bitten member and adversely affects the locoregional prognosis. The local incision increases the risk of contact between the venom and the tissue and the risks of secondary infections or necrosis [7].

Washing and disinfecting the wound will be careful with an antiseptic. Tetanus prophylaxis will be practiced according to the usual in the face of any bite caused by an animal and according to the status of the patient [7].

Any proven poisoning should be the subject of immunotherapy with an appropriate polyvalent antivenom. It is administered either as a $10 \%$ diluted infusion, in $30 \mathrm{~min}$ for $100 \mathrm{ml}$, or in IVD $3 \mathrm{~min}$ for 10 $\mathrm{ml}$. The dosage is directly linked to the evaluation of the severity of the poisoning $[7,8,10,11]$.

\section{Symptomatic treatment will be combined to reduce}

- Pain with paracetamol, codeine, tramadol or a morphine depending on the intensity of the pain.

- Edema: with an NSAID (Ibuprofen $20 \mathrm{mg} / \mathrm{Kg} /$ day).

- Bleeding: by the administration of blood substitutes (fresh blood, fresh frozen plasma) at least 30 minutes after the anti-venom [10].

Our 2 observations showed that just like adults, children too are exposed to the bites of poisonous snakes in tropical countries. These were children of peasants (a 7 year old girl and a 14 year old boy). This socio-economic profile has been described in the literature and by certain authors $[2,12]$.

Our 2 patients were victims of viper bites in the fields. They received anti-venom serum and local care the day of the accident. The poisonings after the bites were later found to be serious. Contrary to the time taken to install the hematological anomalies described in the literature [9], they presented neurological signs a few weeks after the bite with a type of impairment of consciousness and a meningeal syndrome. An emergency brain scan of the girl showed a right subacute hematoma revealing a subarachnoid hemorrhage (Figures 1 and 2). His coagulation balance was not disturbed. Therapeutically she was hospitalized and put on ceftriaxone $100 \mathrm{mg} / \mathrm{Kg} / \mathrm{d}$ for 7 days. Its development has been favorable.

As for the 14-year-old boy, an emergency lumbar puncture led to a hemorrhagic CSF which did not coagulate, thus confirming a subarachnoid hemorrhage. The brain scan also showed a subarachnoid hemorrhage (Figure 3: A, B, C). He died a few hours after his admission to a meningeal syndrome table. This serious clinical picture has been described in the literature [9].

\section{Concludsion}

Snake bites are a common public health problem in tropical regions. Its incidence and progression to severe envenomation is higher in children than in adults.

Unlike other serious medical conditions, there is a very effective treatment (antivenom). However, care is problematic in rural areas due to the breakdown and the high cost of antivenom, but also by the practice of phytopharmacopoeia as a first-line treatment in the event of snake bite.

\section{REFERENCES}

1. Morsures de serpents venimeux [Internet]. [cité 13 sept 2018].

2. Organisation Mondiale de la Santé. Les morsures d'animaux. Genève: Organisation Mondiale de la Santé. 2013; 1(2): 373.

3. Bokata S. Epidémiologie et prise en charge des morsures de serpents dans la province de Bas Congo (République Démocratique du Congo). Bull Société Pathol Exot. 2005; 98(4): 307 - 9.

4. Guyavarch E, Trape J-F. Incidence des morsures de serpent en zone rurale au Sénégal Oriental. Bull Société Pathol Exot. 2005;98(3):198- 9.

5. Adehossi E, Sani R, Boukari-Bawa M. Morsures de serpent à l'Hôpital national de Niamey: à propos de 53 cas. Bull Société Pathol Exot. 2011;104(5):357- 60 .

6. Koné J, Touré MK, Coulibaly S-K. Envenimations ophidiennes: Experience du Centre Hospitalier Universitaire Mère enfant «Le Luxembourg » de Bamako. Rev Afr AnesthésiolMed Urgence. 2017;22(1):30- 4

7. Chippaux J. Envenimations et intoxications par les animaux venimeux ou vénémeux. Inst Rech Pour Dév. 2006;66:423 - 8.

8. Chippaux J. Venin de serpent et envenimations. Institut de Recherche pour le Developpement. Paris: Institut de Recherche pour le Developpement. 2002: 282. (Actiques).

9. Morand J. Envenimations et morsues animales. In: Dermatologie. Elsevier Masson. Paris: Elsevier Masson. 2010: 6. (Elsevier Masson).

10. Chippaux J. Prise en charge des morsures de serpent en Afrique subsaharienne. Médecine Santé Trop. 2015;25:245- 8 .

11. Harry P, Haro L. Traitement des envénimations par les serpents en France. Elsevier Masson. 2002;11: 548- 53.

12. OMS | L'OMS rappelle le besoin vital de sérums antivenimeux [Internet]. WHO. [cité 6 sept 2018]. 